\title{
回転中眼振を対象とした迷路機能の定量法に 関する研究
}

—自記クプロメトリーについて—

東北大学医学部耳鼻咽喉科学教室（主任：片桐主一教授）

估告さ美隆

要 旨 自記クプロメトリー（self-recording cupulometry）の基蕗的問題上臨床応用について述べ た:

われわれが自記クプロメトリーと呼ぶ回転検查は, 回転方式が被検者の感受性いかんに上つて変化 し，その変化する樣相から眩暈の病巣を診断しょうとするものである。したがって，一定の回転方式の 下に迷路反応を測定する従来の検查法とは，全く異つた種類の検查法といらことができる。

初めに基礎編において検查規蕉を定めた。次いで矓最患者 156 例を対象に本検査を施行し，次の結果 を得た。

1. 異常型検出率は85\%で，同一症例における cupulometry $974 \%$ 上りも高い.

2. 自記クプログラムは3つの type に分類できるが, reversion phenomenon 陽性の Type 3 (Reversion type）は例外なく末梢疾患に認められる。

3. 末梢疾患における reversion phenomenon 摘発率は $88 \%$ と極めて高い。したがってこの現象の有 無により，病巣の末梢・中枢鑑別が可能である.

最後に, reversion phenomenon の成因を動物実験により追求した。

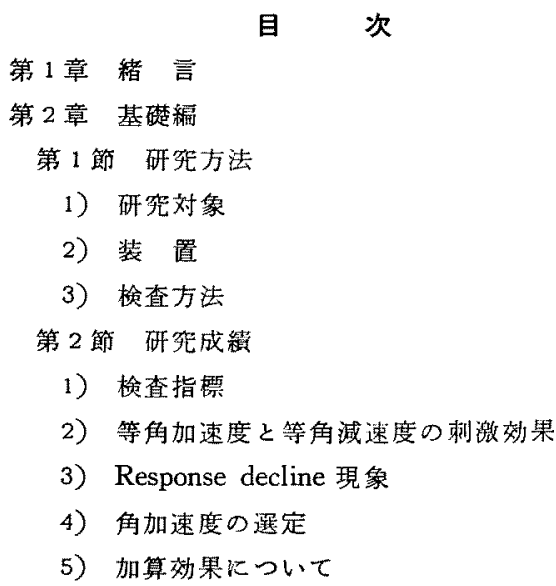

第 3 節 小 括

第 4 節 考 按

1) 回転中眼振を㭘查対象とした理目

2）検查に战ける被检者の負担

3）眼振の检查法及び記録法
4) 自記クプロメトリーの目的 第 3 章 盬床糄

第 1 節 研究方法

1) 研究対像

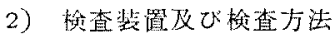

第 2 節 研究成縝

1）自記タプロダラムの分頪

2）自記クブログラム各型と病然部位との関係

3）異常型检出率

4) Vestibular asymmetry の時間的推移

第3 節 考 按

1) 自記クブロメトリーの臨床的特徽

2) Reversion phenomenon の成因について

第 4 章 結 語

文 献

\section{第 1 章 緒言}

前庭平衡機能検查の中で, 適合刺激を用いた唯一の検 隹法である回転検查法は, Bárány ${ }^{12)}$ 端を発するが， 


\section{第1図回転方式の分類}
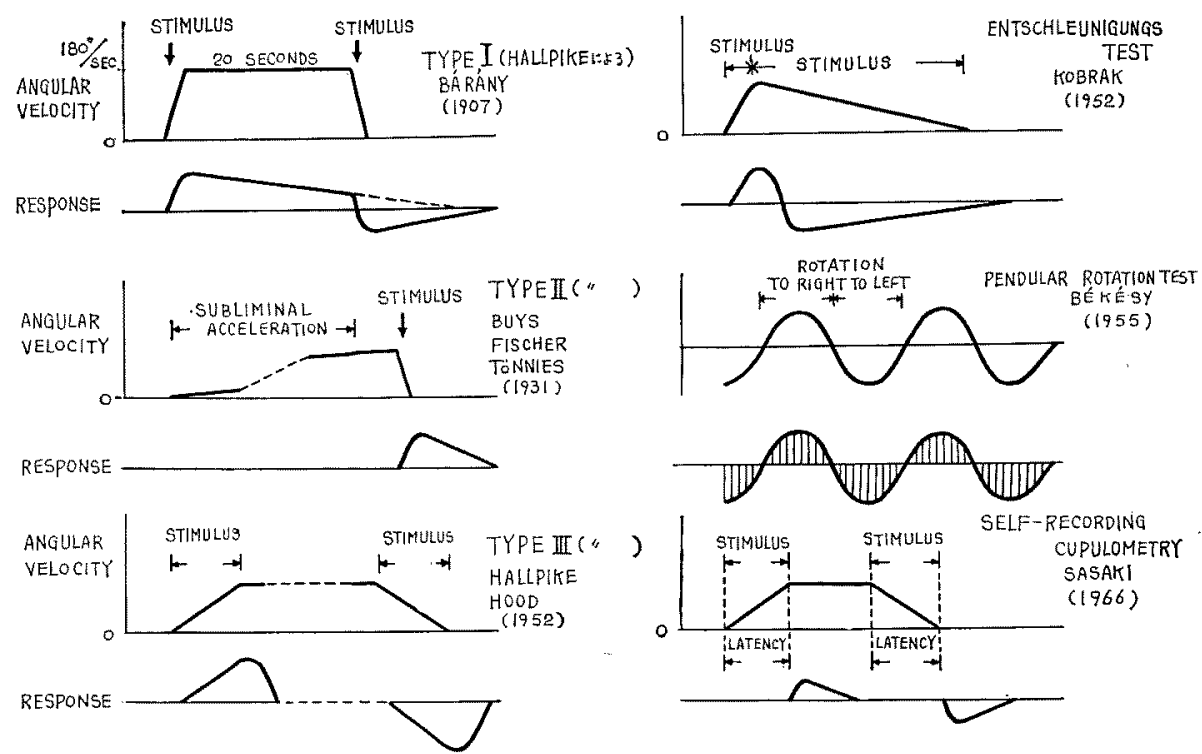

彼の回転法の欠点を補らべく，その後幾つかの回転方式 が考えられている3)(第1図)、1931年 Fischer")等により 閔值下加速 (subliminal acceleration) が提唱され，やが て迷路機能の定量的検查法としての cupulometry が, van Egmond, Groen, Jongkess \& Hulk ${ }^{5) 6)}$ 等によって 考案された，本邦に打いても朴沢78) 等によりこの方面 の研究が行なわれ，その臨床的価值が認められている. しかし，これらの検查法はいずれも回転刺激により諉発 される迷路反応の測定に主眼を括き，しかもその多くが 回転後眼振を対象としてきたため，加えられる刺激が衡 撃的に作用する欠点を有する。この点では，いずれの方 法を Bárány 法と何等変万所がない，回転中眼振を対象 とした㭘查法としては，Aschan ${ }^{9}$, Stahle ${ }^{10)}$ 等による acceleration-deceleration test (AD Test), Kobrak ${ }^{11}$, Wüst ${ }^{192}$ ，朴沢 ${ }^{13)}$ 等による Entschleunigungs-test. Reine-

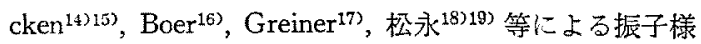
回転検查等を挙げることができるが，これらもまた迷路 反応の測定に主眼をおくものである。

Steinhausen ${ }^{\text {20221 }}$ が Hecht の実験で cupula の偏位を 実証して以来, Mach 及び Breuer の内リンパ流動説は 迷路生理学の主流を占めるに至り，この概念に基づいて 種々の考案がなされている. 著者む同じ立場から，加速 回転中に起る cupula の偏位を想定し，これを回転速度 といら物理的量で表わそうと試みた。
被検者電動式等加速度回転室に入れ，間值上の角加 速度 $\left(+\alpha^{\circ} / \mathrm{sec}^{2}\right)$ で回転すると，一定の潜伏時間の後回 転方向に向う回転中眼振が現われる。この眼振の出現と 同時に等速回転に移し暫くすると，眼振は消失する。 こ こで今度は負の加速度 $\left(-\alpha^{\circ} / \mathrm{sec}^{2}\right)$ を以って刺激すると 前回とは逆に回転方向と反対に向5眼振が見られる。こ の眼振の現われる瞬間を捕らえて再び等速回転に変え る.このような操作を行ないながら，その間に捛ける回 転室の角速度を連続的に記録すれ忹，得られる tachogram が cupula の動きそのものを表わすと考える．か ように著者の考案した方法は，回枟中眼振の発現時期を 指標として，回転中に起る cupula 自身の動きを，使用 する回転室の回転速度という物理的量に還元しながら， 記録しようとするるのである。すなわち，これまで報 告された回転検查は，すべて一定の回転方式（加速度の 大きさ及び刺激時間）の下に迷路反応を測定し，迷路機 能の判定を行な5ものであるが，われわれが自記クプロ メトリー（self-recording cupulometry）上命名した本法 は, その名が示す通り，回転方式が被検者の感受性いか んによっていかようにも変化し得る点特暴である。

\section{第 1 節 研究方法}

\section{第 2 章 基 礎 編}

1) 研究対象

耳疾患の既往なく cupulometry で異常のない正常成人 
第 2 図 電動式等加速度回転室および回転室内 観察用テレビ

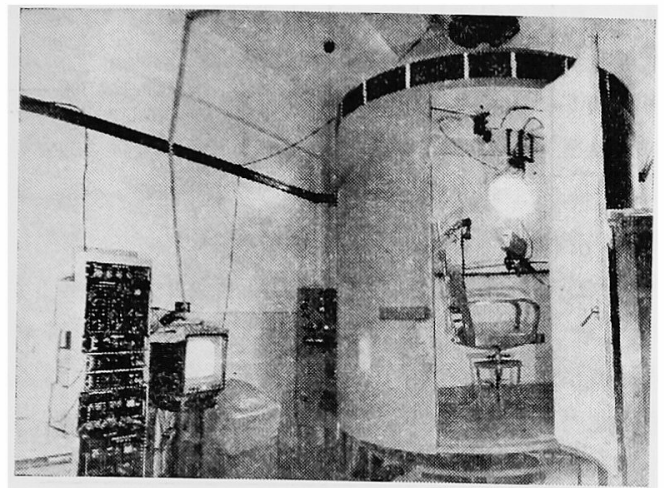

10名, 並びに外来患者50名を研究の対象とした。

2）装 置

a ) 電動式等加速度回転室 ${ }^{22}$ （第 2 図）

この装置は回転室, 減速装置及び制御装置の3つの部 分から成る. 回転室と減速装置は 3 本のV Vベルトにより 連結され，制御装置と減速装置はコントロールロッドで 連絡されている，回転室の角速度は，左右両回転ともに

第 3 図 テレビカメラおよび受像機 ブラウン管上の眼球像

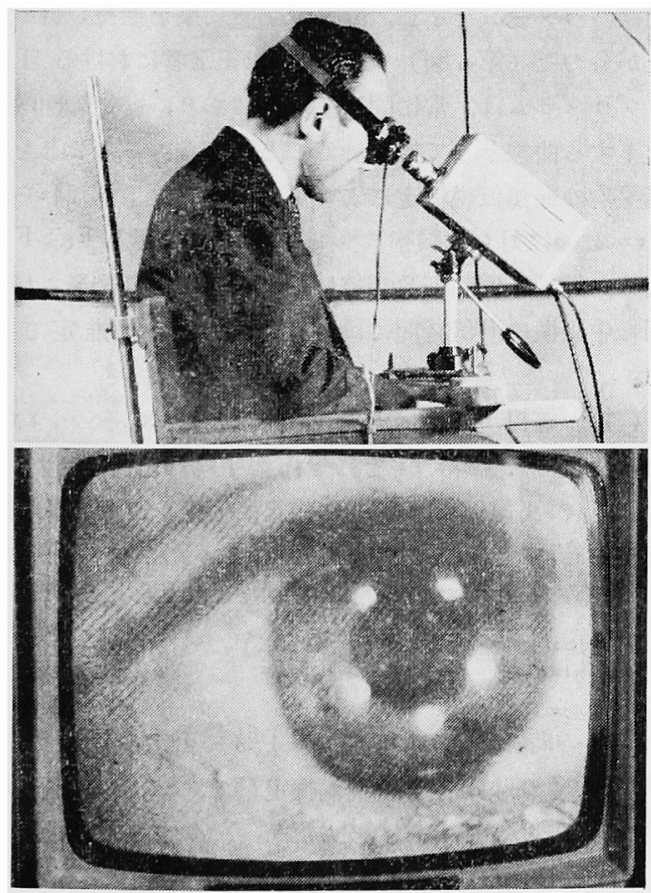

$7.5^{\circ} \sim 120^{\circ} / \mathrm{sec}$ の間で自由に調節される. 角加速度の変 化は可変速摩擦車によつて行ない， $0.4^{\circ} \sim 10^{\circ} / \mathrm{sec}^{2}$ の間 で連続的に増減し得る。

b）回転室内観察用テレビ（第 3 図）

MTC-101-V 型トランジスター化工業用テレビジョン 装置及び専用受像機よりなり, 回転室内の観察の外, 接 写リングを使用することで，室外に備えた受像機のブラ ウン管上に一方の眼を搪大して映し出すことができる. 本機の使用により, 回転中眼振の観察が極めて容易とな った.

第 4 図 自記クプロメトリーの方法

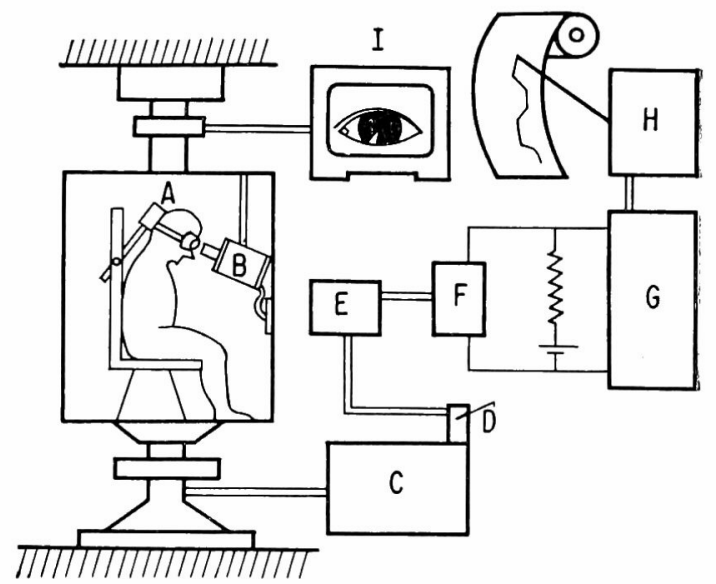
A 東北大加速度回転室
B 回転室内観察用テレビ
C 駆動電動機
$\mathrm{D}$ コンミテーター
$\mathrm{E}$ 制禦電動機
$\mathrm{G}$ 増幅器
$\mathrm{F}$ 回転式可変抵抗器
I 受像機
H オッシログラフ

第 5 図 自記クプロメトリーの原理

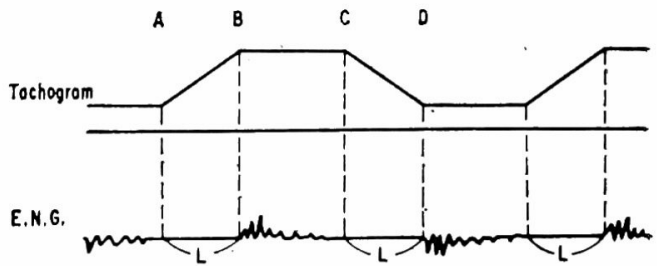

$A-B$ 等角加速度回転

$\mathrm{B}-\mathrm{C}$ 等速回転

$\mathrm{C}-\mathrm{D}$ 等角減速度回転

L 回転中眼振潜伏時間

3）検查方法（第 4，5図）

被検者を回転室中央の椅子に腰掛けさせ, $30^{\circ}$ 前屈の 
位置に頭部を固定寸るとともに，予めテレビカメラに固 定してある改良型フレンツェル眼鏡を着用せしめる。か くして後カメラを僅かに調節すれば，ブラウン管上に一 方の眼を鮮明に㹡大して映し出すことができる。

回転方式は，第 5 図に示したよらな 4 つの回転操作の 連続的組合わせからなつている，その第 1 操作は $+\alpha \%$ sec”の等加速回転で，この操作は眼振の発現まで続けら れる. 眼振の発現と同時に第 2 操作の等速回転に移り， 眼振消失後第 3 操作の $-\alpha^{\circ} / \mathrm{sec}^{2}$ の等減速回転に, 更に 眼振発現と同時に再び等速回転の第 4 操作に移行するも ので, 以上の释過中回転室の速度を連続的にoscillograph によつて記録する、このようにして描出された tachogram は cupulaの動きを間接的に表わ寸と考えた。すな わち, 第 1 操作と第 2 操作の移行点 (B)は回転方向側の cupula $の$ 眼振発現に必要な最小偏位期 (minimal perceptible deflexion) 老, 第 3 操作と第 4 操作の移行点 (D) は反对例の cupulaのそれを表わしていると考える。

操作は，ブラウン管上の眼の動きを指標として，極め て容易に行なうことができる。使用する角速度は，回転 室の特性から各加速度で最む安定した等加速回転の得ら 水る $20^{\circ} \sim 110^{\circ} / \mathrm{sec}$ 附近とし，保加速度には正常人で確 実に回転中眼振の解発される $2^{\circ}, 4^{\circ}, 6^{\circ}, 8^{\circ}, 10^{\circ} / \mathrm{sec}^{2}$ を用いた。

\section{第 2 節 研究成績}

自記クプロメトリ一施行上の問題となる諸点につき検 討を加えた。

\section{1) 検查指標}

検查に当り sensation-cupulogram 同様被検者の回転感 觉を指標として目的に適つた結果が得られるならテレ ビによる眼振観察の手数は省かれることになる。しか し，感覚といら客観化の困難な現象を検查の指標とする ことには大いに疑問がある，従来，検査に際し前庭迷路 を純反射器とする見方と感覚器とする見方とがあるが23， 前庭迷路の前庭神経終末装置は位置変化及び運動に対し て receptorとしての役割を持ち，その反応忙飽迄反射的 に意識下に筋緊張に作用するものであり，前庭迷路は反 射器上見做す心゙きである。かかる前庭迷路を平衡保持に 関与する他の諸々の感覚器の作用から分離するには，眼 振を検查の指標とするのがより妥当と思われる。

正常者につき，回転中眼振及び回転感覚のそれぞれを 指標として得られた潜伏時閒の標淮偏差 $(\sigma)$ 比較して みると, 前者で $\sigma_{N}=1.4$ に対し後者は $\sigma S=3.6$ と遥かに 大きなバラッキを示した.これは眼振を指標とすること
第 6 図 等角加減速度の刺激効果（3 例平均）

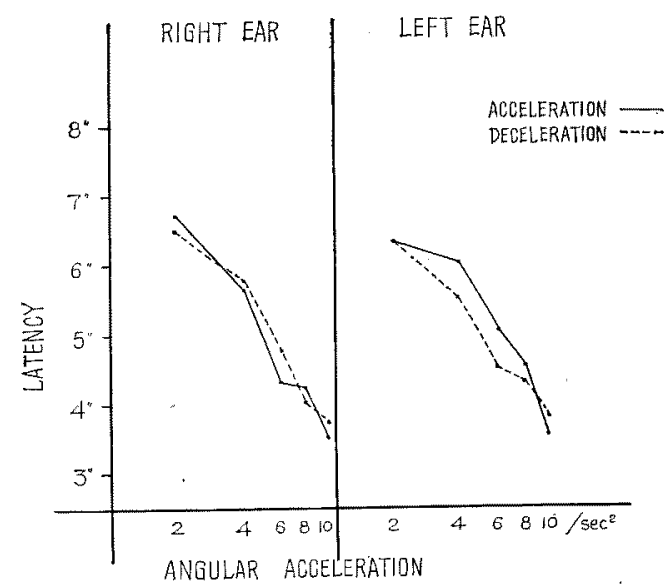

の假位を裹付けるものである。

2）等伯加速度之等角減速度の刺激效果

本検查は，一方向回転において加速減速を行ない，こ れにより解発される左右方向への回転中眼振潜伏時間の 差を問題とするものであるから，回軽室の等角加減速度 は正確に同等の剌激效果をむたらすものでなければなら ない。そこで同一人につき左在雨回転定行ないlatency cupulogram を作製してみると，加速・減速ともにほぼ 同様のパターンを示し, 同等の刺激效果を期待し得るこ とが分つた（第6図），したがつて正常者に持ける自記 クプログラムは，常に同一基線上にあり，一定範囲内を 上下する曲線として描かれることになる。このことを等 母平均の帰無仮説検定により更に確認した。すなるち, $\mathrm{F}_{S}=0.03$ に対し危険率 $5 \%$ で $\mathrm{F}_{S}=4.04$ を示し $\mathrm{F}_{S}>\mathrm{F}$ と なり，等加速度回転及び等減速度回転により誘発される 回転中眼振の潜伏時閒には有意の差がないと推定され Ђ.

（註）等母平均の帰無仮説 ${ }^{24)}$ とは, $\left(\mathrm{x}_{1}, \mathrm{x}_{2}, \cdots \cdots, \mathrm{x}_{N_{1}}\right)$ $\left(\mathrm{y}_{1}, \mathrm{y}_{2}, \cdots \cdots, \mathrm{y}_{\mathrm{n}}\right)$ がそ扎ぞれ母平均 $\mathrm{m}_{1}, \mathrm{~m}_{\mathrm{g}}$ ，母分散 $\sigma^{2}{ }_{1} ， \sigma_{2}^{2}$ の正規母集団加らの相互に独立した 無作為標本 である時， $\sigma_{1}=\sigma_{0}$ であるから， $\mathrm{m}_{\mathrm{i}}=\mathrm{m}_{2}$ の仮説の下では，

$$
\begin{aligned}
& \mathrm{W}^{\mathrm{n}}=\mathrm{Sx}+\mathrm{Sy} / \mathrm{N}_{1}+\mathrm{N}_{2}-2 \\
& \mathrm{~F}_{S}=(\mathrm{x}-\overline{\mathrm{y}})^{2} / \mathrm{W}^{2}\left(1 / \mathrm{N}_{1}+1 / \mathrm{N}_{2}\right) \\
& \mathrm{F}_{n \mathrm{n}=N_{1}+N_{0-1}}^{n \mathrm{l}=1} \quad(\alpha=0.01)
\end{aligned}
$$

$\mathrm{F} S>\mathrm{F}$ の時， $\mathrm{m}_{1}=\mathrm{m}_{2}$ は危険率 $1 \%$ で否定できる，なお W"は共通の母分散 $\sigma^{2}$ の不偏推定量で，Sx，Sy は標本変 動である。

3) Response decline 現象 
回転刺激反復による反応減弱は現在定説であり"55:6), Hood \& Pfaltzにより response decline と命名されたこ の現象の存在は, 回転検査に当り無視できぬ問題とされ ている。しかし一方Hood \& Pfaltz ${ }^{26)}$ ，小倉 ${ }^{27)}$, Fluur ${ }^{28)}$ 等は，回転中眼振の潜伏時間は反復刺激によつても著明 な変化を示さないとしており，この点を確認するために 次のような実験を行なつた。

正常者について等角加減速度による刺激を前述の方法 にしたがい10回反復し，測定值（潜伏時間）の推計学的 検查加ら個人変動につき考察した，10回連続記 録した tachegram の初めの 3 回と終りの 3 回には有意の差がな く,これより本検査において response decline 現象の影 觢は無視できると考えた $\left(F_{S}=3.86\right.$ に対し危険率 $5 \%$ で $\mathrm{F}=4.13$ を示し $F_{S}>\mathrm{F}$ となる).

4）角加速度の選定（第 7 図）

等速回転が認識されず, 唯陰陽の角加速度のみが回転 覚を引き起すことが Mach 以来知られている. その閾值 に関してはいろいろな報告を見ることができるが，1\% $\sec ^{2}$ 前後に求めるむのが圧倒的に多い早．著者は以上の 報告並びに回転室の性能を考慮の上， $2^{\circ} ， 4^{\circ}, 6^{\circ}, 8^{\circ}$, $10^{\circ} / \mathrm{sec}^{2}$ の角加速度を検查に使用した。

しかし，臨床上本検查を施行する場合，以上 5 種の角 加速度すべてにわたる検查は煩雑であり, 診断上不必要
第 7 图 加速度別左右差正常限界

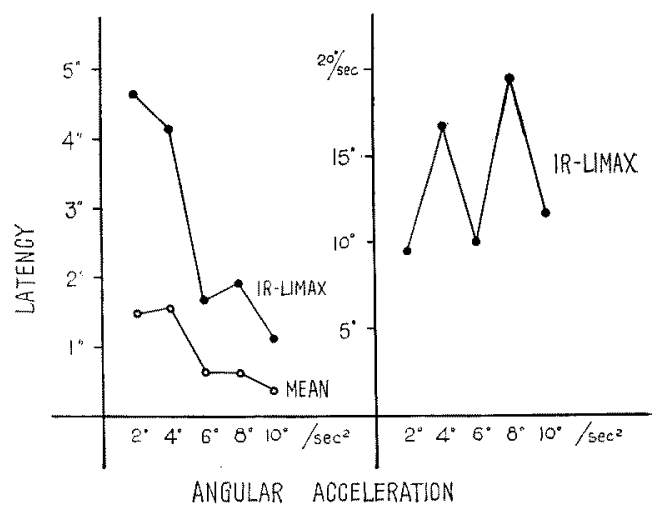

註）IR-LIMAX は左右差の最大を示す

でもあるため，角加速度を更に精選することとした，各 加速度における左右差の正常限界は第 7 図に示したごと くである。この成績を参考に，バラッキが比較的少く刺. 激が強・中・弱に及.5 $2^{\circ}, 6^{\circ}, 10^{\circ} / \mathrm{sec}^{2}$ の 種を選出し た。これは本法が cupulometry 同様にパターンテスト であるため，成績に方向性を付する意味から最小限 3 点 における検查が必要と考えたからである.

5）加算効果について（第 8 図）

第 8 図 加算効果について (反復検查による正常限界並びに異常発現率の変動)

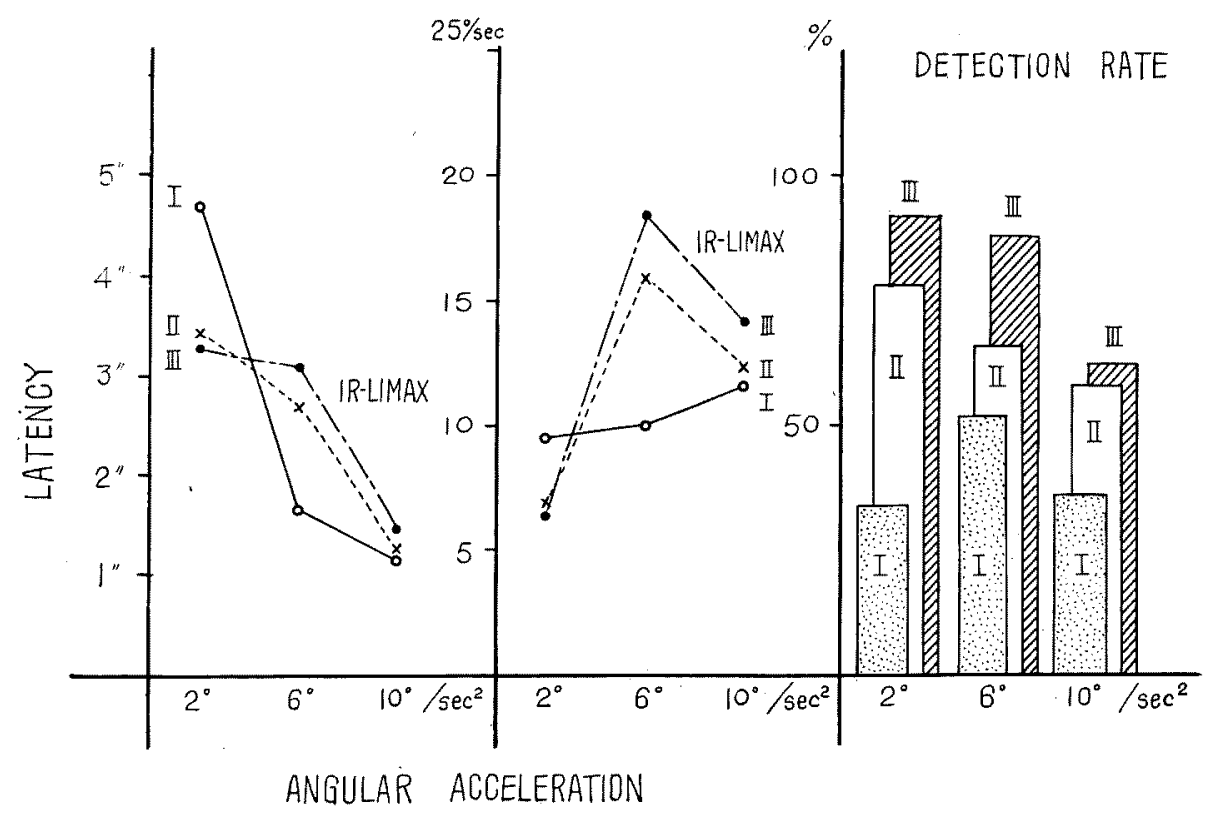


本検查は左右回転中眼振の潜伏時間を比較することに より行ならが，検査成績に確実性を加える一方，潜伏時 間に左右差ある場合その莮加により著明な変化としてこ れを把握するためには，前述の回転操作孛何度か反復す る方法が考えられる。 response decline 現象は10回程度 の反復では問題とならないが, 被検者の負担や検査の迅 速性超えると無暗にこれを絽返えすことはでさない． 常識的にも 2 度乃至 3 度の反復にとどまることになる が，果してこの程度の絽返えしがとれだけの意味を有す るか？この点を検討した。

正常者成績加 $2^{\circ}, 6^{\circ}, 10^{\circ} / \mathrm{sec}^{\prime} \sigma$ 角加速度について, 1，2，3回の各反復に括ける左右差の正常限界を決定 した. しかる後, 外来患者50名を対象に上記の正常限界 に添つて各反復検査時の異常発現率を算出した, その結 果は第8図に示したごとくである.すなわち, 刺激の反 復により正常限界は $2 \% \mathrm{sec}^{2}$ 除いて搪がる傾向を示した が，病的症例における左右差はこれを上回る加算効果を 表わし, 異常発現率は 2 回の反復更に 3 回の反復によつ て著明な上昇を呈した。

第 3 節 小括

以上の結果から，自記クプロメトリーの㮩查規準を次 のごとく定めた.

1. 検査は左右いずれかの一方向加減速回転により行 なう。ただし, vestibular asymmetry (VAと略す) 陽性 の場合曲線が常に上昇する型上して描かれるように，眼 振の出難い方向に向つて回軾制激を加えた。

2. $20 \% / \mathrm{sec}$ の等速回転を以つて始め, 使用する等角 加速度は $2^{\circ} ， 6^{\circ}, 10^{\circ} / \mathrm{sec}^{\circ} の 3$ 種とした。

3. 各加速度について検查を 3 回反復して行なら.

4. 結果の判定は，回転室タコグラムの初速と終速の 差を以つて行な5. 而して, $2^{\circ}, 6^{\circ}, 10^{\circ} / \mathrm{sec}^{2} の$ 各加速 度について左右差が $10^{\circ}, 20^{\circ}, 15^{\circ} / \mathrm{sec}$ 在越寸場合異常 と判定した。

\section{第 4 節 考 按}

\section{1) 回転中眼振を検査対象とした理由}

回転中眼振の観察は，等角加減速度という単純な連続 刺激に対し平衡老保持しようとする全迷路系の能動的態 度老掌握する上に，有力な手段上考えられている。これ に対し，従来検查対象として摖々用いられている回転後 眼振に亚，種々非迷路性要素の介入が起り易く，迷路本 来の機能を知るには不都合な点が多い. Mittermaier \&

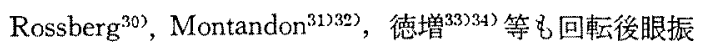
が回転中眼振に比しバラッキの大きいことを報告してい
吕:

このような長所を有するにもかかわらず，回転中眼振 がこれまで臨床検查法にあまり取入れられなかつた理由 は, 先ず第 1 に, 回転中眼振の解発には通常等角加減速 度が使われるため，検査に精密な回枟装置を必要とする ことが挙げられる，そして又，回転中眼振の観察・記録 が困難なことも理由の1つであろら，現在最も震々用い られる electronystagmography（ENGよ略す）によつて も，この問題は解決し尽くされていない，記録に際し起 り勝ちな雑音の混入は ${ }^{35}$, 特に回転中眼振の記録におい て大きな障害となり，眼振波形の忠実な描写が時に不可 能とさえなる。

著者は，電動式等加速度回転空及び回転室内観察用テ レビの使用により，これらの問題を解決するととむに， ENGによつては記録が不可能とされている回転中眼振 の first slow phase 正確に捕えることに成功した.

2) 娭查に拝ける被娭者の負担

検查に使用する觔加速度は $2^{\circ}, 6^{\circ}, 10^{\circ} / \mathrm{sec}^{\mathrm{n}}$ の 3 種で あるが、、ずれも first slow phase の出現と同時に中断 されるため，不快な自律神経症状の現われることは少 い.この点同じ回転中眼振老刘象とした検査法でも Hallpike $e^{32}$, Mittermaier \& Rcssberg*0), Montandon ${ }^{3(3) 37)}$, Stahle ${ }^{10)}$ Collins \& Guedry ${ }^{38)}$, 小含 ${ }^{27)}$, 德増 ${ }^{33734)}$ 等の 使用した検查法, すなわち閶值上の加速度を眼振の出現 と注関係なく一定時關負荷する方活よりる，さらに被検 者の受ける負担が少い上うに思われる。

3）眼振の検查法及じ記録法

眼振を記録観察する方法は Högyes (1881) 以来種々考 案されているが399，機㭜的方法はすでに過去のものとな り，今日では主として電気的あるいは光電学的方法が使 用されている、電気的方法は，1939年 Jung \& Mittermaier ${ }^{40)}$ が眼振運動に伴う電位差の変動を oscillcscope により記録したのが初まりである。その後 Fitzgerald, Cawthorn \& Hallpikeが温塺刺激後の眼振持続時閒を記 録し，以来目覚しい発展在遂げた。しかしこの方法にむ 前述のごとき知点が残されている. Torok ${ }^{41)}(1951)$ ， Pfaltz \& Richter')(1956)により始められた光電学的方 法にむ同様の久点がある゙ ${ }^{43)}$. Hallpike \& Hood(1953)等 によつて行なわれている prismatic periscopeによる回転 中眼振緩徐畨の観察は，以上の方法における人工座物の 介入を恐れた結果と思われる。

著者も，非常に複雑な眼の動きの中から正しく眼振を゙ 読み取る方法は, 被検者の眼党搪大して直接観察する以 
外にないと考えている，特に微細なものの多い回転中眼 振の観察には，テレビで眼を搪大観察する方法が威力を 発揮する。この方法の短所は記録性に欠ける点にあつた が，朴沢による telenystagmography ${ }^{4+1}$ の考案により ENG 同様にブラウン管上の眼の動きを波形として記録 紙上に描写できるようになった，又この分野におけるど デオコーダーの導入はさらに進んだ解決策となつた。映 像の再現に上り，記録性と同時に検查成績に確実性を加 えることができる。

4) 自記クプロメトリーの目的

前庭平衡機能検查法の進歩発展は, 神経耳科学的診断 上切実な問題と考えられる.疾患の中枢か未梢かを鑑別 し,さらに進んで病䉓の所在, 障害側を決定し，障害の程 度や病期を明らかにすることは神経耳科学上特に望まれ る点であるが,これらの要望を完全に満し得る検查法は 末だ確立されていない，検查法の簡略化もその普及に不 可欠の条件であるが，かかる現況においては方法の煩 雑さや装置の大きさの問題を越えて, 上記の要望を少し でも忠実に満す検査法の確立こそ焦眉の急と思われる。 著者はかくのごとき観点から本検査法を企画した。

\section{第 3 章 臨 床 編}

\section{第 1 節 研究方法}

1) 研究対象

当教室で前庭平衡機能検查を施行した患者中次に揭げ る156 例を観察の対象とした。

1. 末梢疾患

(57 例)

a. $x=エ ル$ 病

b. 内耳性難聴

c. 末梢性顔面神経麻瘦

d. 艺の他

2. 中枢疾患
a. 天幕上疾患
b. 小㯌・脑幹部疾患
c. 膇腫演の疑
d. その他

3. 小䏼橋角部疾患

4. 顽部外傷

5. 形性丧量

6. 眩暈症 25例 9例 12例 11 例 (40例) 10 例 7例 12例

2）検查装置及び検查方法

基礎編と同し。。

\section{第 2 節 研究成繥}

成績の判定は基礎編に記した規準にしたがい行なつ
た、VAの有無は十，一を以つて表わし，便宜上陽性例 をさらにasymmetryの程度で第 1 表のごとく+，H．H の3段階に分類した。

第 1 表 判 定 規 集

\begin{tabular}{|c|c|c|c|}
\hline 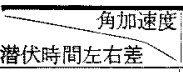 & $2^{\circ} / \mathrm{sec}^{\mathrm{n}}$ & $6^{\circ} / \sec ^{2}$ & $10^{\circ} / \mathrm{sec}^{2}$ \\
\hline+ & $10^{\circ} \sim 30^{\circ} / \mathrm{sec}$ & $20^{\circ} \sim 40^{\circ} / \mathrm{sec}$ & $15^{\circ} \sim 35^{\circ} / \mathrm{sec}$ \\
\hline H & $30^{\circ} \sim 50^{\circ} / \mathrm{sec}$ & $40^{\circ} \sim 60^{\circ} / \mathrm{sec}$ & $35^{\circ} \sim 55^{\circ} / \mathrm{sec}$ \\
\hline$H$ & $50^{\circ} / \mathrm{sec} \sim$ & $60^{\circ} / \mathrm{sec} \sim$ & $55^{\circ} / \mathrm{sec} \sim$ \\
\hline
\end{tabular}

第9図 自記クプログラムの分類

Type I

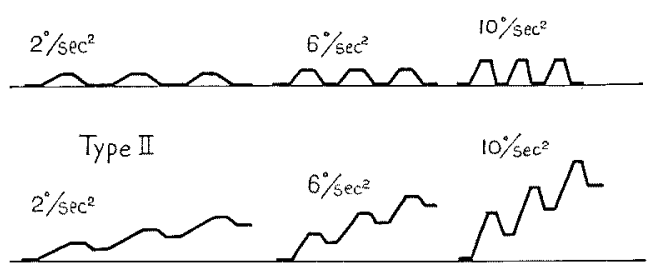

Type III

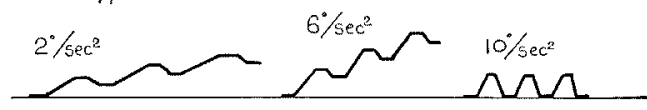

1）自記クプログラムの分類（第 9 図）

臨床例 156 症例対象に検查を行なった結果, 自記夕 プログラムに 3 種のパターンがあるのを知つた。これを シェーマで示すと第9図のごとくである。

Type 1 (Normal type)：曲線がいずれの加速度にお いても同一基線上に描かれるもので, VA 陰性の正常型 と考えられる. 基礎編で正常人が示した曲線はこの type に属する。

Type 2 (Divergence type) : 加速度の増強とともに VA も增大し，曲線が次第に基線から遠く離孔る type.

Type 3 (Reversion type): 弱刺激で基線加ら離れて いた曲線が，刺激の増強とともに再び基線に近づく傾向 を示すtypeである。

2）自記クプログラム各型と病巣部位との関係

次に, 検查対象中病巣所在の明らかな81例の検查成績 を部位別に表示すると，第2，第3表のごとくである. 又，検查対象全例を type により分類したのが第 4 表で ある、いずれも cupulometry の成績と対比する型で表 わした。 
第 2 表 自記クプログラム各型と病单部位との関係（末梢疾患）

\begin{tabular}{|c|c|c|c|c|c|c|c|c|c|c|c|c|c|c|c|}
\hline \multirow{2}{*}{$\begin{array}{l}\text { 症 } \\
\text { 例 }\end{array}$} & \multirow{2}{*}{$\begin{array}{l}\text { 性 } \\
\text { 別 }\end{array}$} & \multirow{2}{*}{$\begin{array}{l}\text { 年 } \\
\text { 令 }\end{array}$} & \multirow{2}{*}{\multicolumn{2}{|c|}{ 診 }} & \multirow{2}{*}{ 断 } & \multirow{2}{*}{\multicolumn{2}{|c|}{ 名 }} & \multirow{2}{*}{$\begin{array}{l}\text { 患 } \\
\text { 側 }\end{array}$} & \multirow{2}{*}{\multicolumn{2}{|c|}{ クプログラム }} & \multicolumn{5}{|c|}{ 自記クプログラム } \\
\hline & & & & & & & & & & & $2 \% \mathrm{sec}^{2}$ & $\% / \mathrm{sec}^{2}$ & $10^{\circ} / \mathrm{sec}^{2}$ & 回転方 向 & Type \\
\hline 1 & $\delta$ & 38 & $x$ & $=$ & 工 & ル & 症 & 左 & D P & L. & + & + & - & C.W.R. & III \\
\hline 2 & $q$ & 30 & & & $\prime \prime$ & & & 右 & $\mathrm{DP}$ & R. & H & H & - & a.C.W.R. & III \\
\hline 3 & $\hat{s}$ & 44 & & & $\prime \prime$ & & & 右 & $\mathrm{DP}$ & $\mathrm{R}$. & H & - & - & a.C.W.R. & III \\
\hline 4 & $\delta$ & 40 & & & $" \prime$ & & & 右 & D P & R. & H & - & - & a.C.W.R. & III \\
\hline 5 & $\delta$ & 57 & & & $" \prime$ & & & t & $\mathrm{DP}$ & $\mathrm{L}$. & $H$ & H & - & C.W.R. & III \\
\hline 6 & 웅 & 25 & & & $" \prime$ & & & 左 & $\mathrm{DP}$ & $\mathrm{L}$. & $H$ & - & + & C.W.R. & III \\
\hline 7 & $\delta$ & 47 & & & $" \prime$ & & & 左 & normal & & $H$ & - & - & C.W.R. & III \\
\hline 8 & $\hat{o}$ & 50 & & & $" \prime$ & & & 右 & $\mathrm{DP}$ & L. & + & - & - & C.W.R. & III \\
\hline 9 & $q$ & 17 & & & $\prime \prime$ & & & 右 & $\mathrm{DP}$ & L. & + & + & - & C.W.R. & III \\
\hline 10 & $\hat{s}$ & 60 & & & $" \prime$ & & & 右 & $\mathrm{CP}$ & $\mathrm{R}$. & $H$ & H & - & C.W.R. & III \\
\hline 11 & $q$ & 28 & & & " & & & 右 & D P & L. & $H$ & $H$ & - & C.W.R. & III \\
\hline 12 & $\hat{o}$ & 44 & & & $" \prime$ & & & 左 & $\mathrm{DP}$ & $\mathrm{R}$. & $H$ & $H$ & - & a.C.W.R. & III \\
\hline 13 & $q$ & 43 & & & $\prime \prime$ & & & 左 & D P & $\mathrm{R}$. & $H$ & H & \pm & a.C.W.R. & III \\
\hline 14 & $\hat{o}$ & 56 & & & $\prime \prime$ & & & 左 & D P & $\mathrm{R}$. & H & + & - & a.C.W.R. & III \\
\hline 15 & q & 45 & & & $\prime \prime$ & & & 左 & D P & $\mathrm{R}$. & $H$ & + & - & a.C.W.R. & III \\
\hline 16 & $\&$ & 17 & & & $" \prime$ & & & 左 & D P & $\mathrm{R}$. & + & $H$ & - & a.C.W.R. & III \\
\hline 17 & $\hat{o}$ & 29 & & & $" 1$ & & & 右 & $\mathrm{CP}$ & $\mathrm{R}$. & $H$ & H & - & C.W.R. & III \\
\hline 18 & $q$ & 55 & & & $\prime \prime$ & & & 左 & D P & $\mathrm{R}$. & + & - & - & a.C.W.R. & III \\
\hline 19 & $\delta$ & 47 & & & $\prime \prime$ & & & 左. & $\mathrm{DP}$ & $\mathrm{R}$. & + & - & - & a.C.W.R. & III \\
\hline 20 & $\hat{o}$ & 32 & & & " & & & 右 & D P & $\mathrm{L}$. & + & - & - & C.W.R. & III \\
\hline 21 & $q$ & 26 & & & $\prime \prime$ & & & 右 & $\mathrm{CP}$ & R. & H & H & - & C.W.R. & III \\
\hline 22 & $\hat{\delta}$ & 56 & & & $\prime \prime$ & & & 右 & normal & & + & - & - & C.W.R. & III \\
\hline 23 & $\hat{o}$ & 37 & & & $" \prime$ & & & 右 & $\mathrm{DP}$ & $\mathrm{R}$. & - & - & - & C.W.R. \& a.C.W.R. & I \\
\hline 24 & 운 & 49 & & & $\prime \prime$ & & & 左 & $\mathrm{CP}$ & $\mathrm{L}$. & + & - & - & a.C.W.R. & III \\
\hline 25 & $\hat{o}$ & 40 & & & $\prime \prime$ & & & 右 & D P & $\mathrm{L}$. & + & - & - & C.W.R. & III \\
\hline 26 & 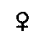 & 42 & 内 & 耳 & 性 英 & 難 耳 & 聴 & 左 & DP & L. & $H$ & - & - & C.W.R. & III \\
\hline 27 & $\hat{o}$ & 28 & & & $\prime \prime$ & & & 左 & DP & R. & H & + & - & a.C.W.R. & III \\
\hline 28 & $\hat{o}$ & 27 & & & $\prime \prime$ & & & 左 & $\mathrm{DP}$ & $\mathrm{R}$. & H & H & - & a.C.W.R. & III \\
\hline 29 & $\hat{\delta}$ & 39 & & & $" \prime$ & & & 右 & D P & L. & \# & - & - & C.W.R. & III \\
\hline 30 & $\delta$ & 44 & & & $" \prime$ & & & 両 & normal & & - & - & - & C.W.R. \& a.C.W.R. & I \\
\hline 31 & $q$ & 25 & & & $" \prime$ & & & 左 & $\mathrm{DP}$ & $\mathrm{R}$. & + & + & - & C.W.R. & III \\
\hline 32 & $q$ & 27 & & & $" \prime$ & & & 右 & normal & & - & - & - & C.W.R. \& a.C.W.R. & I \\
\hline 33 & $q$ & 32 & & & $\prime \prime$ & & & 右 & normal & & - & - & - & C.W.R. \& a.C.W.R. & I \\
\hline 34 & $q$ & 23 & & & $" \prime$ & & & 右 & normal & & - & - & - & C.W.R. \& a.C.W.R. & I \\
\hline 35 & $\hat{3}$ & 42 & 慢 & 性 & 中 $\mathrm{E}$ & 耳 & 炎 & 右 & $\mathrm{DP}$ & $\mathrm{R}$. & H & + & - & a.C.W.R. & III \\
\hline 36 & $\$$ & 29 & & & $\prime \prime$ & & & 右 & $\mathrm{DP}$ & $\mathrm{R}$. & $H$ & + & \pm & a.C.W.R. & III \\
\hline 37 & $\hat{o}$ & 29 & & & $" \prime$ & & & 両 & normal & & + & - & - & a.C.W.R. & III \\
\hline 38 & $\delta$ & 25 & & & $\prime \prime$ & & & 右 & D P & $\mathrm{L}$. & + & + & - & C.W.R. & III \\
\hline 39 & $\hat{o}$ & 20 & 迷 & 路 & 梅 & F & 毒 & 左 & $\mathrm{CP}$ & $\mathrm{L}$. & $H$ & - & - & a.C.W.R. & III \\
\hline 40 & $q$ & 56 & & & $" \prime$ & & & 左 & DP & $\mathrm{R}$. & + & - & - & a.C.W.R. & III \\
\hline 41 & $\delta$ & 27 & 迷 & 路 & 振 & 䫖 & 症 & 左 & $\mathrm{DP}$ & $\mathrm{R}$. & H & $H$ & - & a.C.R.W. & III \\
\hline 42 & $\delta$ & 31 & 迷 & 路 & 骨 & & 折 & 左 & D P & L. & + & + & - & C.W.R. & III \\
\hline
\end{tabular}




\begin{tabular}{|c|c|c|c|c|c|c|c|c|c|c|c|}
\hline \multirow{2}{*}{$\begin{array}{l}\text { 症 } \\
\text { 例 }\end{array}$} & \multirow{2}{*}{$\begin{array}{l}\text { 性 } \\
\text { 別 }\end{array}$} & \multirow{2}{*}{$\begin{array}{l}\text { 年 } \\
\text { 令 }\end{array}$} & \multirow{2}{*}{ 診断 名 } & \multirow{2}{*}{$\begin{array}{l}\text { 患 } \\
\text { 側 }\end{array}$} & \multirow{2}{*}{\multicolumn{2}{|c|}{ クプログラム }} & \multicolumn{5}{|c|}{ 自記クプログラム } \\
\hline & & & & & & & $2 \% / \sec ^{2}$ & $6^{\circ} / \mathrm{sec}^{\mathrm{2}}$ & $10^{\circ} / \mathrm{sec}^{2}$ & 回転方 向 & Type \\
\hline 43 & $\delta$ & 29 & 耳 下 腺 雪是 & 左 & D P & L. & $H$ & + & - & C.W.R. & III \\
\hline 44 & $\hat{o}$ & 44 & 前庭神経元炎 & $?$ & $\mathrm{DP}$ & L. & $H$ & + & - & C.W.R. & III \\
\hline 45 & $q$ & 39 & $\prime \prime$ & 左 & D P & $\mathrm{R}$. & H & H & \pm & a.C.W.R. & III \\
\hline 46 & $\hat{\delta}$ & 45 & 末梢性顔面神経麻源 & 左 & D P & L. & Ht & + & - & C.W.R. & III \\
\hline 47 & 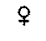 & 64 & "' & 左 & D P & L. & - & - & - & C.W.R. \& a.C.W.R & I \\
\hline 48 & $q$ & 24 & $\prime \prime$ & 左 & D P & $\mathrm{R}$. & $H$ & $+t$ & - & a.C.W.R. & III \\
\hline 49 & 우 & 20 & "' & 右 & norme & & $H$ & HH & + & C.W.R. & III \\
\hline 50 & 우 & 49 & $\prime \prime$ & 右 & D P & $\mathrm{R}$. & + & - & - & a.C.W.R. & III \\
\hline 51 & ㅇ & 23 & "' & t & D P & $\mathrm{R}$. & + & - & - & a.C.W.R. & III \\
\hline 52 & $\hat{\delta}$ & 20 & "' & 右 & C P & $\mathrm{R}$. & $H$ & $H$ & - & C.W.R. & III \\
\hline 53 & 9 & 26 & "I & 左 & $\mathrm{DP}$ & $\mathrm{R}$ & $H$ & $H$ & - & a.C.W.R. & III \\
\hline 54 & q & 18 & $\prime \prime$ & 右 & norm & & H & + & - & a.C.W.R. & III \\
\hline 55 & $q$ & 19 & $\prime \prime$ & 右 & D P & $\mathrm{L}$. & + & + & - & C.W.R. & III \\
\hline 56 & $\hat{o}$ & 71 & " & 左 & $\mathrm{DP}$ & $\mathrm{R}$. & $H$ & H & - & a.C.W.R. & III \\
\hline 57 & $\hat{o}$ & 37 & $" \prime$ & 右 & norm & & - & - & - & C.W.R. \& a.C.W.R & I \\
\hline
\end{tabular}

C.W.R. : clcckwise rotation

a.C.W.R. : anticlockwise rotation

第 3 表 自記クプログラム各型と病眘部位との関係（中枢疾患）

\begin{tabular}{|c|c|c|c|c|c|c|c|c|c|c|}
\hline \multirow{2}{*}{$\begin{array}{l}\text { 症 } \\
\text { 例 }\end{array}$} & \multirow{2}{*}{$\begin{array}{l}\text { 性 } \\
\text { 別 }\end{array}$} & \multirow{2}{*}{$\begin{array}{l}\text { 年 } \\
\text { 令 }\end{array}$} & \multirow{2}{*}{ 診 断 名 } & \multirow{2}{*}{$\begin{array}{l}\text { 患 } \\
\text { 側 }\end{array}$} & \multirow{2}{*}{ クプログラム } & \multicolumn{5}{|c|}{ 自記クプログラム } \\
\hline & & & & & & $2 \% / \mathrm{sec}^{2}$ & $6 \% \mathrm{sec}^{2}$ & $10 \% \mathrm{sec}^{2}$ & 回転方向 & Type \\
\hline 1 & $\hat{o}$ & 21 & 側 頭 葉 腫 瘍 & 左 & normal & - & $H$ & H & C.W.R. & II \\
\hline 2 & $\hat{\delta}$ & 34 & " & 左 & D P L. & H & H & H & C.W.R. & II \\
\hline 3 & $\delta$ & 12 & " & 左 & D P L. & H & H & $H$ & C.W.R. & II \\
\hline 4 & $\delta$ & 13 & $\prime \prime$ & 左 & D P L. & H & H & H & C.W.R. & II \\
\hline 5 & 운 & 54 & 側 腷 室 腫 瑒 & 左 & $\mathrm{DP} \quad \mathrm{R}$. & $H$ & + & H & C.W.R. & II \\
\hline 6 & $q$ & 30 & 脳底部硬膜外腫瘍 & 右 & $\mathrm{DP} \quad \mathrm{R}$ & H & H & H & a.C.W.R. & II \\
\hline 7 & $\hat{\delta}$ & 31 & 前頭 葉 腫 瘍 & 左 & DP L. & + & + & H & C.W.R. & II \\
\hline 8 & $\hat{o}$ & 31 & 側頭 部 硬膜下血腯 & 左 & DP L. & $H$ & + & $H$ & C.W.R. & II \\
\hline 9 & $\hat{o}$ & 17 & $\prime \prime$ & 左 & DP $\quad \mathrm{L}$ & + & H & $H$ & C.W.R. & II \\
\hline 10 & 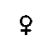 & 23 & 遒 & 左 & D P L. & H & H & $H$ & C.W.R. & II \\
\hline 11 & $\hat{o}$ & 15 & 小脑畽瘍 & 右 & $\mathrm{DP} \quad \mathrm{R}$. & $H$ & H & $H$ & a.C.W.R. & II \\
\hline 12 & $q$ & 38 & " & 左 & DP $R$. & + & H & H & a.C.W.R. & II \\
\hline 13 & $\hat{o}$ & 28 & 松 菓 腺 腫 & 右>左 & DP L. & H & H & H & C.W.R. & II \\
\hline 14 & $\hat{\delta}$ & 48 & 媨下垂体缠瘍 & 右>左 & $\mathrm{DP} \quad \mathrm{R}$. & H & + & H & a.C.W.R. & II \\
\hline 15 & $\delta$ & 27 & " & 右 $>$ 左 & D P L. & H & \# & H & C.W.R. & II \\
\hline 16 & $q$ & 13 & 第四脳室腫瘍 & 正中 & normal & - & - & - & C.W.R. \& a.C.W.R & I \\
\hline 17 & 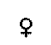 & 21 & 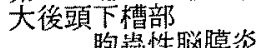 & 正中 & D P L. & H & $H$ & $H$ & C.W.R. & II \\
\hline 18 & $q$ & 30 & 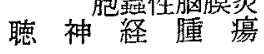 & 左 & normal & - & - & H & C.W.R. & II \\
\hline 19 & $\hat{\delta}$ & 44 & " & 右 & DP L. & + & $H$ & $H$ & a.C.W.R. & II \\
\hline 20 & $q$ & 39 & $\prime \prime$ & 右 & DP R. & Ht & H & $H$ & C.W.R. & II \\
\hline 21 & q & 49 & $\prime \prime$ & 右 & $\mathrm{DP} \quad \mathrm{R}$. & H & H & $H$ & C.W.R. & II \\
\hline
\end{tabular}




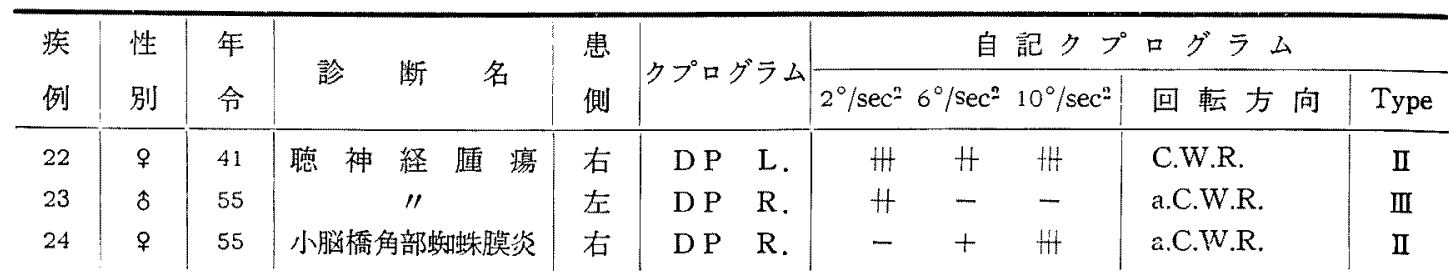

C.W.R. : clockwise rotation

a.C.W.R. : anticlockwise rotation

第 4 表 検 查 成 績

\begin{tabular}{|c|c|c|c|c|c|c|c|c|}
\hline \multirow{2}{*}{\multicolumn{2}{|c|}{ 疾 患 名 }} & \multirow{2}{*}{ 例 } & \multicolumn{3}{|c|}{ クプログラム } & \multicolumn{3}{|c|}{$\begin{array}{l}\text { 自記クプログ } \\
\text { ラム }\end{array}$} \\
\hline & & & 正常 & $\begin{array}{l}\text { 平行 } \\
\text { 型 }\end{array}$ & 㝔叉 & $\left|\begin{array}{c}\text { Type } \\
\text { I }\end{array}\right|$ & $\left|\begin{array}{c}\text { Type } \\
\text { II }\end{array}\right|$ & $\begin{array}{c}\text { Type } \\
\text { III }\end{array}$ \\
\hline \multirow{2}{*}{ 未 } & メニエル病 & 25 & $\cdots$ & $:::::$ & & - & & $\mid:::::$ \\
\hline & 内耳性難聴 & 9 & $\cdots$ & $\cdots \cdots \mid$ & & $\cdots$ & & $\cdots$ \\
\hline $\begin{array}{l}\text { 梢 } \\
\text { 疾 }\end{array}$ & 傯庭神経元 & 2 & & $\cdots$ & & & & $\cdots$ \\
\hline \multirow[t]{2}{*}{ 患 } & 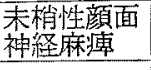 & 12 & $\cdots$ & $::: \cdot$ & & $\cdots$ & & $:::::$ \\
\hline & その他 & 9 & $\cdot$ & $: \because \cdots$ & & & & $::::$ \\
\hline 中 & 天幕上疾患 & $\mid 10$ & & $::: \cdot$ & & & $:::::$ & \\
\hline 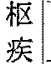 & $\begin{array}{l}\text { 小䏼・䐉幹 } \\
\text { 部疾患 }\end{array}$ & 7 & & $\because \cdots$ & & $\cdot$ & $\cdots$ & \\
\hline 患 & $\begin{array}{l}\text { 小俄橋角部 } \\
\text { 疾虫 }\end{array}$ & 7 & & $\because \cdots$ & & & $\cdots \cdots$ & |. \\
\hline \multicolumn{2}{|c|}{ 脑腄瘍の疑 } & 12 & $\cdots$ & $:::$ & & 1 & $::::$ & \\
\hline \multicolumn{2}{|c|}{$\begin{array}{l}\text { その他の中枢 } \\
\text { 疾患 }\end{array}$} & 11 & $\cdots$ & $: \cdots+$ & & & $::: \cdot \cdot$ & \\
\hline \multicolumn{2}{|c|}{ 頭 部 外 偒 } & 13 & $\because:$ & $\because \cdot$ & & $\cdots$ & $:: \cdots$ & \\
\hline \multicolumn{2}{|c|}{ 莖面性眩最 } & 11 & $\cdots$ & $: \cdots \cdots$ & & $\because$ & $\cdots$ & $\because \cdots$ \\
\hline & 最 症 & 28 & & $:::::$ & & & & \\
\hline
\end{tabular}

こ机らの成績から，自記クプログラム各型と病巣部位 との間に，次の上らな特異的関倸を熟めた。

1. Type 2 (Divergence type) は中枢疾患に限り見 られる(第10図)。

2. Type 3 (Reversion type) 沬末梢疾患上小檤橋角 部疾患の一部に見られる(第11図).

3）異常型検出率 (第12図)

本法の異常型検出率は約85\%を示した。 これは同一症 例を対象として得られた cupulometry の74\%, Mann's test $065 \%$ ，Arm-tonus reaction $027 \%$ 上り高い陽性率 である。

\section{4） VA の時問的推移}

平衡障害の経時的変化を忠実に followすること永，前 庭平衡機能検查にとつて重要な条件上考えられる。殊に 臨床症状が常に浮動して止まないメ二エル病を初めとす る末梢疾患に沶いて住，現在ある病期を正確に把提寸る ことが治療方針を立てる上に不可欠のことと思われる ${ }^{45)}$.

著者は既述の観察対象の中上り少くとも2 度以上梌查 を行なつた症例を選び出し，自記クプログラムにおける VA の時間的推移を観察した，その結果を同時に施行し た cupulometry 並びに温度検查の成績と比較しながら， 代表的症例に上り説明する。

症例 1 金○千

病名 メニエル病 (左)

検查成績（第i図）

術前VAはいずれの検查に括いても著明である。ポル トマン手術後は，自覚症の消失とともに自記クプログラ ム・クプログラムの回転検查成績に改善名みられる。し かし，カロリグラムには全経過を通じ大きな変化を認め ない.

$$
\begin{aligned}
& \text { 症例 } 2 \text { 石○素○ } 20 才 \quad \text { ㅇ } \\
& \text { 病名 ハント症候群 (右) } \\
& \text { 検查成績 (第14図) }
\end{aligned}
$$

興味ある眼振経過を示した症例である。初診時認めら れた健側 (左) 向自発眼振は, 経過中にその方向を転し て患側 (右) 向を示している。この患側向眼振は中枢代 償により現われた Stenger のいらErholungsnystagmus ${ }^{46}$ ) と考えられるが，この時期は短く眼振は再び健側に向い 治烝機転の複雑さを示している，回転桧查成綘はこの症 例に掠いても病期に適つた結果を示すが，カロリグラム には終始変化がない。

症例 3 内○孙 30 \%

病名 小媨橋角部聥瘍 (左)

検査成績（第15図）

手術後整く見られた自発眼振は次第に減弱し，回転検 

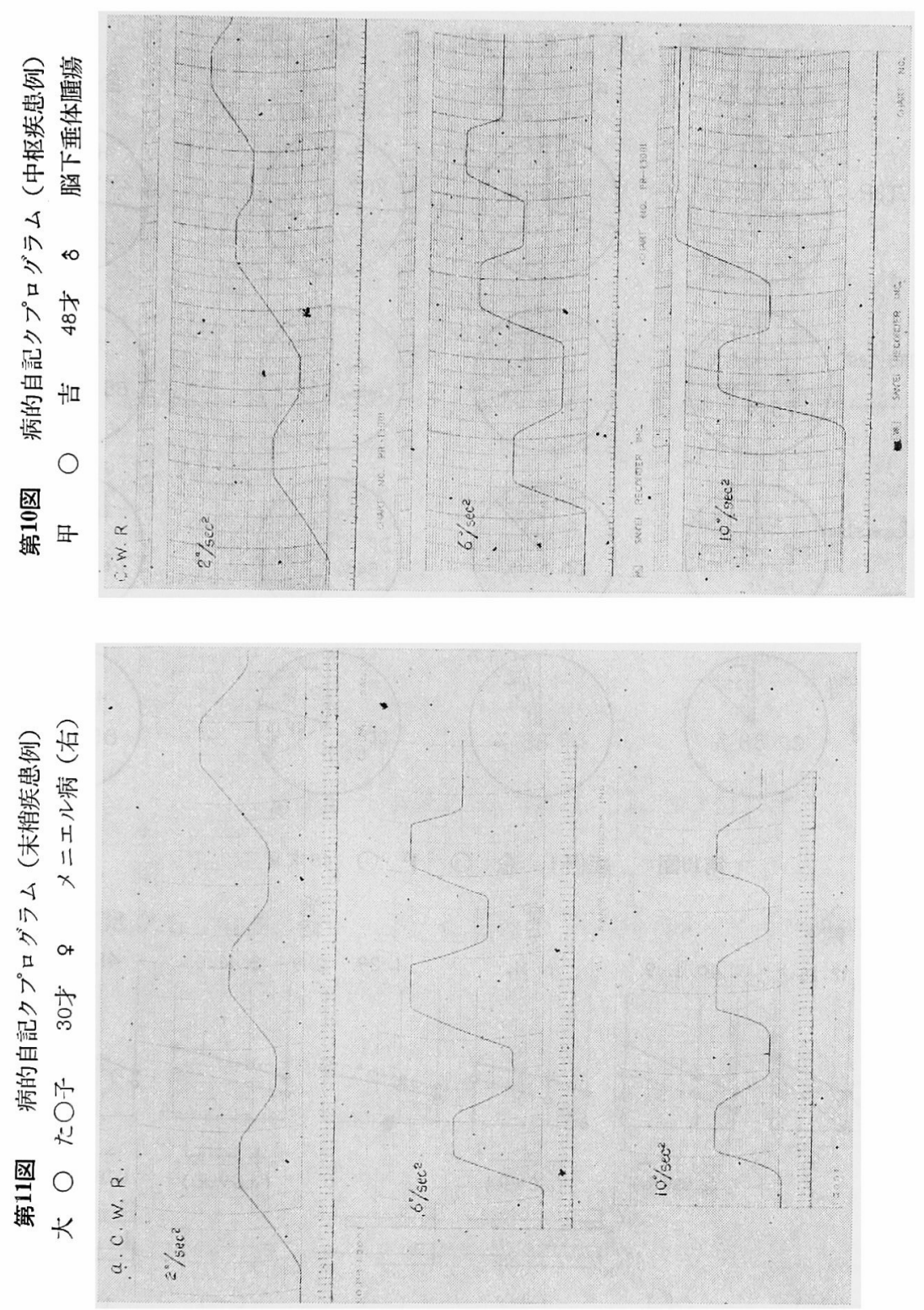

査成績も正常化の傾向を示寸.しかし，自覚的にめまい の消失した状態に至つても, カロリグラムには改善の徴 候がない.

以上のような傾向はその他の症例にも見られる.すな わち，自記クプログラムを含めて回転検査成績は平衡障 害の経時的変化を忠実に follow し, 病期を他覚的に知 る上に有意義である一方, カロリグラムが治療の前後を 通じてほとんど一定した成績を示し, 病期を知る拠り所
として不適当なことが分つた.

第 3 節 考 按

1）自記クプロメトリーの臨床的特徵

以上の研究結果を通じて得られた自記クプロメトリー の臨床的特徴は次のごとくである.

1. 自記クプログラムは正常型の Type 1 と, 異常型 である Type 2, Type 3 に分類できる.

2. Type 2 (Divergence type) は中枢疾患に限り, 又 
第12図異常型検出率

末梢疾患

A.T.R.
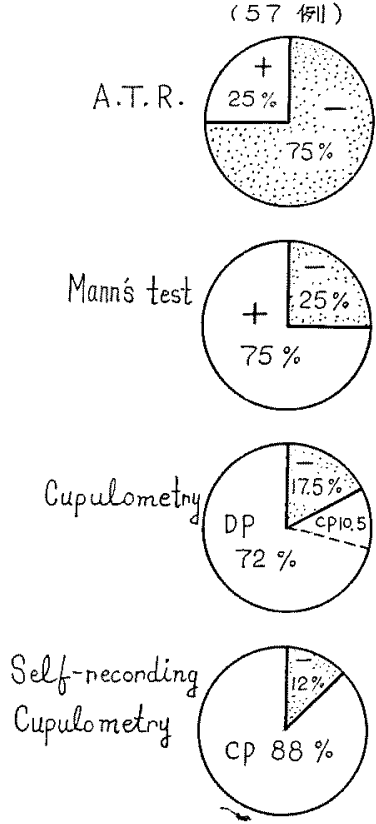
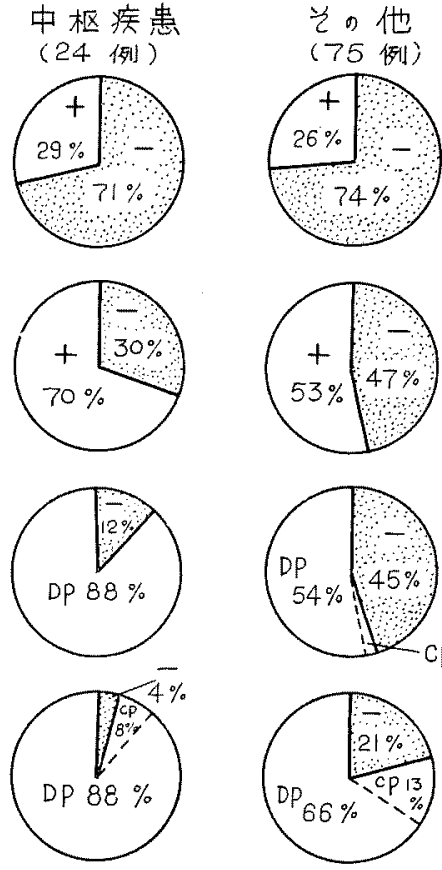
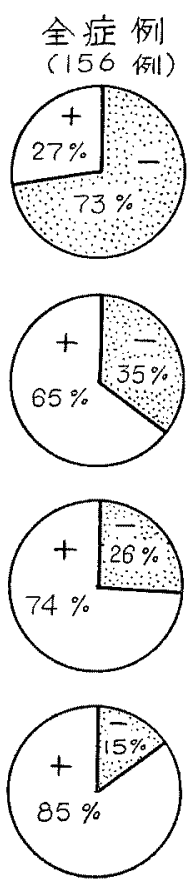

第13図 症例 1 金 $\bigcirc$ 千 $\bigcirc 45$ 才。

院

39.12 .4 .

12. 18.

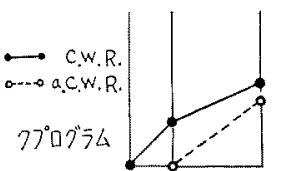

自記

加リブラム

めまい（十）

自発眼振 (一)
40. 1. 9 .

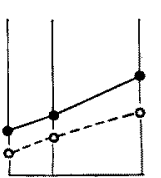

$++($ (a.C.W.R.)

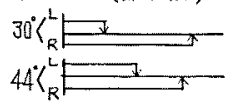

(t)

(t)

$(-)$

$(-)$

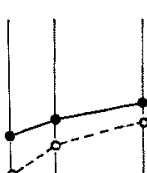

$++$

楚

1.11 .

1. 29.2 .19

3. 16.
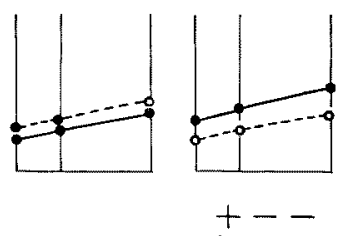

(a.C.W.R.)

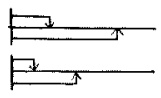

(-)

$(-)$

(-)

(一)
41. 2. 15.

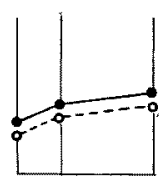

(C.WR.\& A.C...R.)

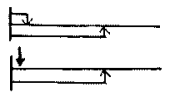

$(-)$

$(-)$
Type 3 (Reversion type) は末梢疾患と一部の小媨橋角 部疾患に見られる。

3. 異常型検出率は約85\%である。これは同一症例を 対象として得られた他の検查法 (cupulometry etc.) よ り商い晹性率である。

4.本法により見出されるVAは，平衡障害の経時的
変化を忠実に followし，病期を他覚的に知る重要な手照 となる。

5. 末梢疾患における reversion phenomenon の摘発 率は $88 \%$ と極めて高く，この現象の有無により病单の末 佾・中枢鑑別が可能である。

6. 欠点は, 第 2 度以上の自発眼振例に検查を行なえ 


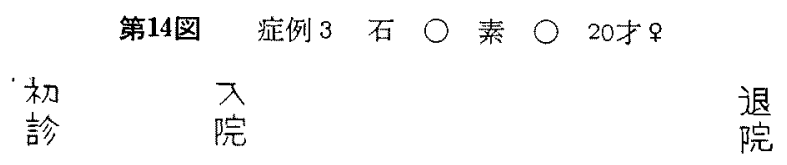
41. 4.6
4. 15
4. 22
5. 2
6. 10
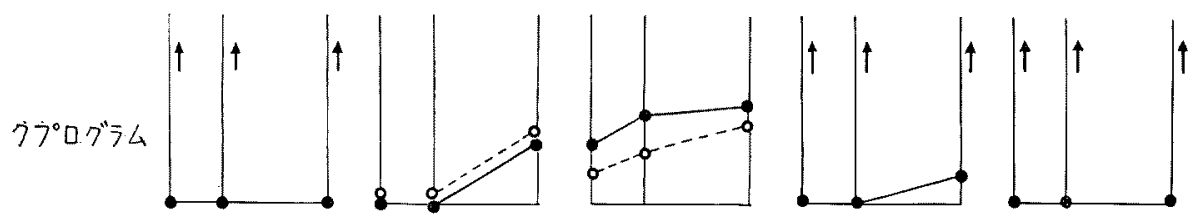

自記

フプログラム

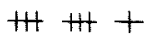

$++$

(回転方向)

(C.W.R.)

(C.W.R.)

カロリグラム

めまり (H)
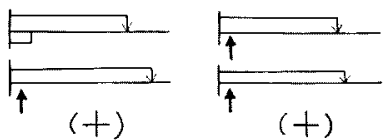

自発眼振
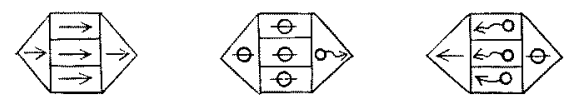

(士)

$\pm$

手

第15図症例 4 内 $\bigcirc$ み $\bigcirc$ 30才ㅇ

38. 7. . 10.8 .

39. 4.23.

11. 30 .

40. 7. 2 .

クプログラム
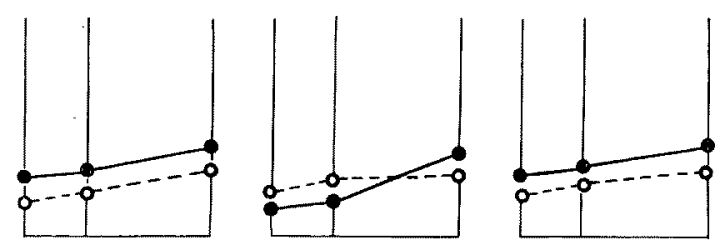

自記

$77^{\circ} 07^{4} ラ 4$

カロリブラム
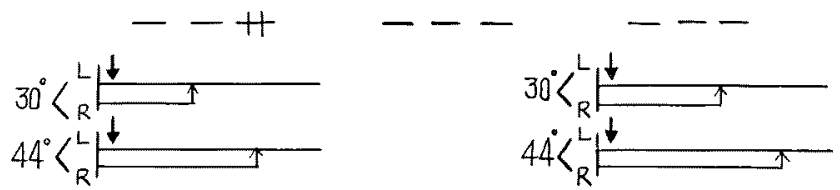

めまし

$(+)$

$( \pm)$

$( \pm)$

(土)

自発眼振
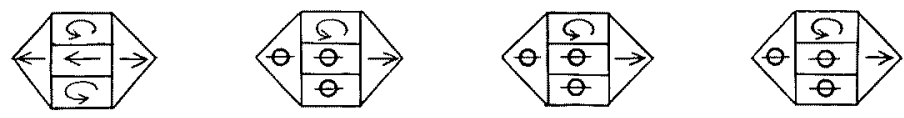

ず，患側決定が不可能なことと，特種設備を要する点で ある.

2) Reversion phenomenon の成因について

自記クプロメトリーの特徴を一言にして表わすなら， 病巣の末梢・中枢鑑別が可能な点である，以下，この鑑 別の重要な手照である reversion phenomenonの成因に 
ついて考察する.

Dix 等がコルチ器の毛細胞に病変ある場合聴覚に recruitment 現象が認められると発表して以来, cochlear recruitmentの検査は内耳性難聴と後迷路性難聴の鑑別上 重要な手段とされている47)48).

一方，前庭反応にも同様の現象があることを Azzi， Gioridano \& Spelta ${ }^{49}$ (1953)が報告して以来, vestibular recruitment の存在は大方の見解とされている. 過去に おける報告をみると，朴沢7)(1957)，Albano ${ }^{50)}$ (1958), 松永 $^{18)}$ (1962), Horak ${ }^{51)}$ (1963), Greiner ${ }^{52)}$ (1964), 池 田 ${ }^{53)}$ (1964) 等は回転検查により, Azzi ${ }^{49)}$ (1953), 武山 ${ }^{64)}$ (1958), 猪 • 岡本 ${ }^{55)}(1959)$, 小池 ${ }^{56)}(1964)$ 等は温度 検査により本現象の存在を見出した。 そしていずれの報 告者もこの現象を末梢迷路に特有の徴候と考えている.

著者が reversion phenomenon と呼んでいるのは, 弱 刺激で明らかな回転中眼振潜伏時間の左右 差が, 刺激 （加速度）の增大とともに縮小若しくは消失する現象で， cochlear recruitment あるいは vestibular recruitment に 極めて類似のものと考えられる.

自記クプログラムの Type 3 は本現象の存在を示すも のであるが，臨床上この type を示すものは主として末 梢疾患に限定され，中枢疾患にはこれを全く認めない.
すなわち，本現象も又 vestibular recruitment 同様に末 梢迷路の徵候と考えられる. この点を更に動物実験によ り確認した.

a）実験方法と観察方法

実験動物には $200 \mathrm{~g}$ 前後の正常モルモット6 匹を使用 した. 鼓膜・外耳道に暴常なく, プライエル耳介反射正 常，自発眼振・頭位眼振を認めず，代償性眼球偏位正 常, 体位・向位反射ともに正常で, 自記クプロメトリー の結果VAのないものを正常とした.

これら正常モルモットを $\mathrm{A} ， \mathrm{~B}$ の 2 群に分ち，それぞ れを次のごとく処理した。

A 群：硫酸ストマイの鼓室内注入

硫酸ストマイを sprase (hyaluronidase)で溶解し, こ の溶液を経外耳道に 3 匹のモルモットの右鼓室腟内人注 入，これを中 1 日おいて 2 度反復施行した. この結果, 初回注入後 4 日目に至り右プライエル耳介反射並びに代 償性眼球偏位の減弱及び頭位眼振を認めた。

$\mathrm{B}$ 群：異物の頭蓋内扦入

残り 3 匹に対し右側頭骨硬膜外にはんだの球を挿入し た（第16図）。

かくのごとく処理した 2 群のモルモットにつき，4 日 後自記クプロメトリーを行なつた．なお，モルモットは

第16図頭蓋内異物㨂入モルモットX線像
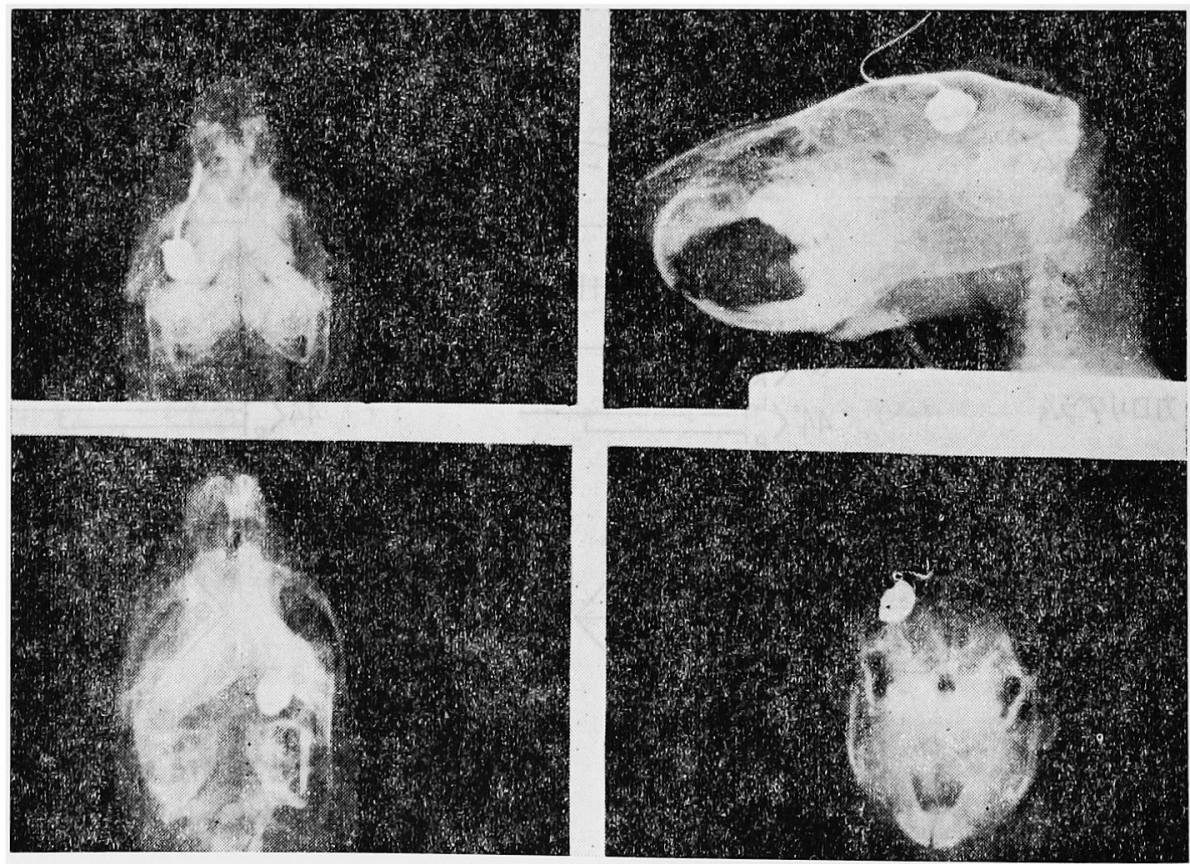
第17図ＳMモルモットが示した自記クプログラム
$S M$ 注入前
$\mathrm{S} M$ 注入後

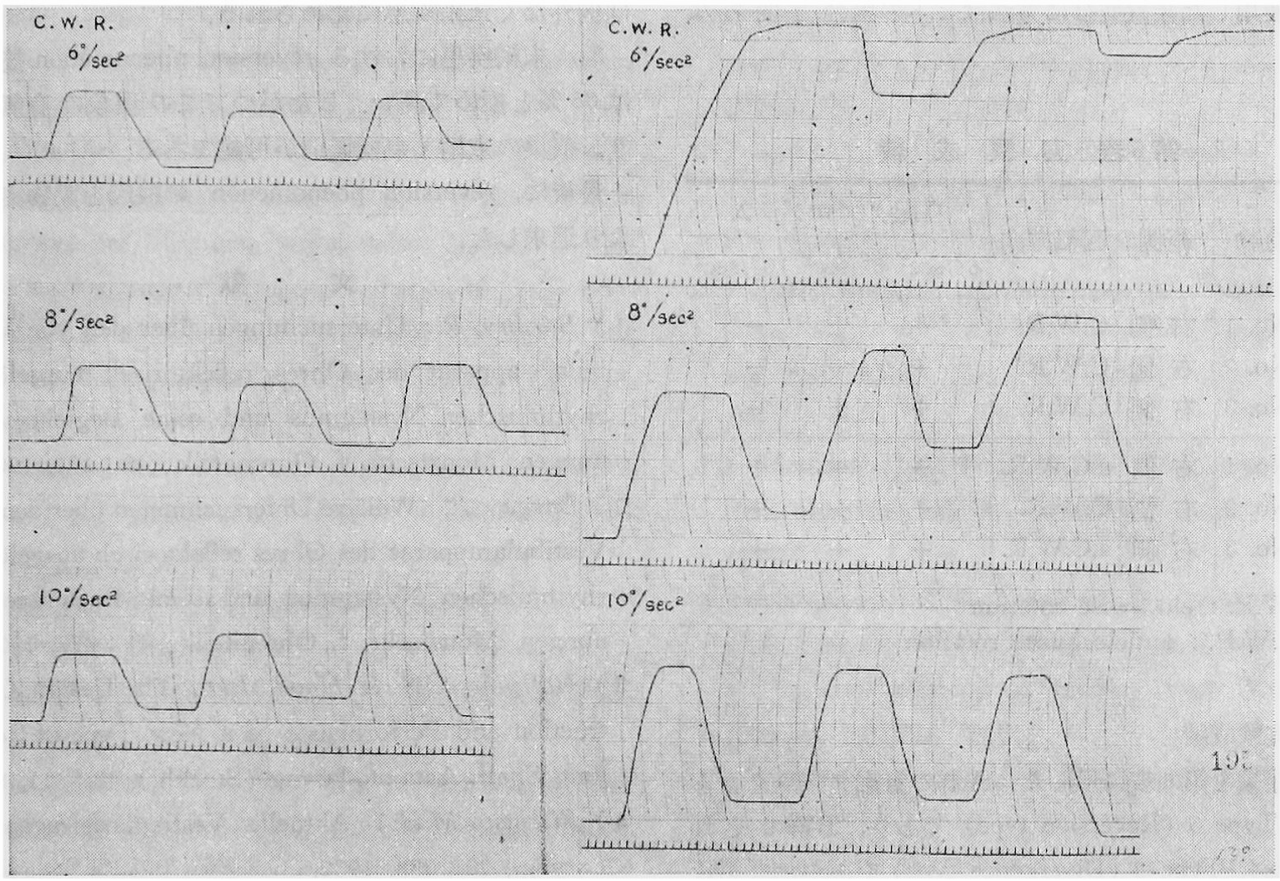

第18図頭蓋内異物挿入モルモットが示した自記クプログラム

異物 插入前
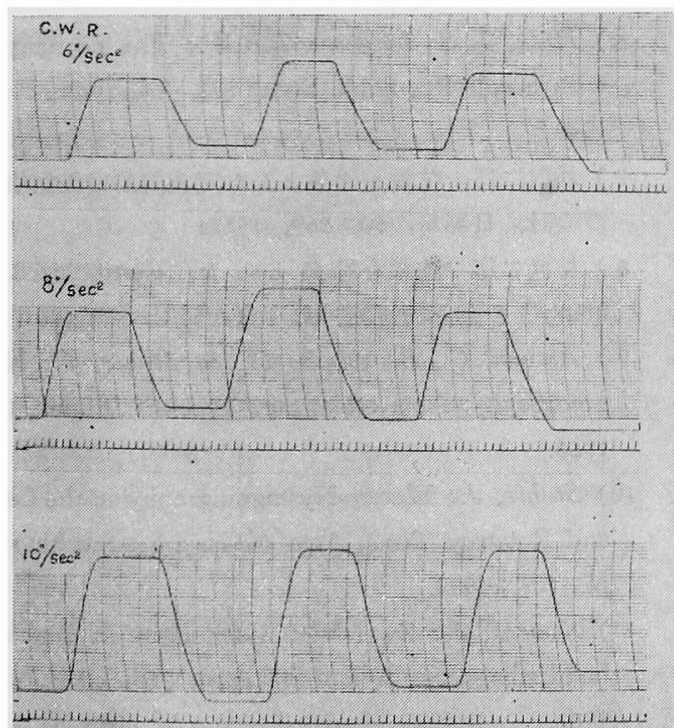

$9-45$
異物插入後

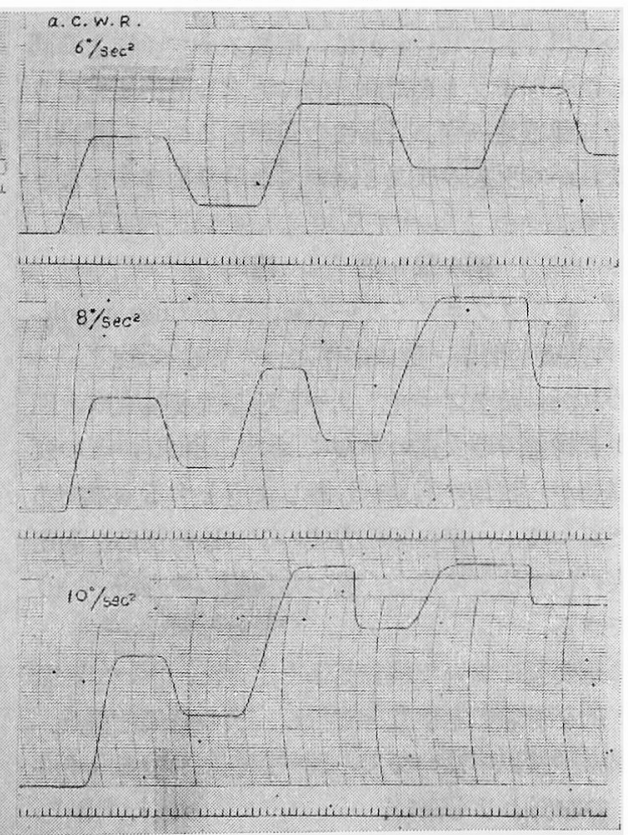


ヒトに比し水平半規管の角加速度刺激に対する閥值が高 いため，検查には $6^{\circ} ， 8^{\circ}, 10^{\circ} / \mathrm{sec}^{2} の$ 角加速度を用いた。 検査に使用した装置並びに方法はヒトの場合と変らな W.

第 5 表 実 験 成 續

\begin{tabular}{|c|c|c|c|c|c|c|}
\hline \multirow{2}{*}{\multicolumn{2}{|c|}{ 実験動物 }} & \multirow{2}{*}{ 術側 } & \multirow{2}{*}{ 回転方向 } & \multicolumn{3}{|c|}{ 自記クプログラム } \\
\hline & & & & \multicolumn{3}{|c|}{$6 \% \sec ^{2} 8^{\circ} / \sec ^{2} \quad 10^{\circ} / \mathrm{sec}^{\circ}$} \\
\hline 不注 & No. 1 & 右 側 & C.W.R. & + & \pm & - \\
\hline 卜 & No. 2 & 右 側 & C.W.R. & + & + & - \\
\hline 人例 & No. 3 & 右 側 & C.W.R. & + & \pm & - \\
\hline 異插 & No. 1 & 右 側 & a.C.W.R. & + & + & + \\
\hline 入 & No. 2 & 右 側 & C.W.R. & + & + & + \\
\hline 物例 & No. 3 & 右 側 & a.C.W.R. & + & + & + \\
\hline
\end{tabular}

\section{b）実験成績}

実験結果を第 5 表に示した、A群の自記クプログラム は全て Type 3 (Reversion type) であり，B群のそれ はいずれも Type 2 (Divergence type) であつた（第17 18 国)

この結果は，reversion phenomenonが末梢迷路に由来 するとする臨休的見解を裏付けるるのである。

教室の池田 (学) ${ }^{5 \pi}$ (1965) は, 硫酸ストマイにより同 様処理したモルモットを電顕学的に追求し，半規管ぽ 大部稜の二種感覚細胞に受傷性の差があることを見出し たが，これが本現象の成因と深いつながり有するよう に思われる。

\section{第 4 章 結 語}

要 旨 自記クプロメトリー（self-recording cupulometry）の基礎的問題と臨床応用について述べた。

われわれが自記クプロメトリーと呼ぶ回転検查は, 回 転方式が被検者の感受性いかんによつて变化し, その変 化する様相加ら矓最の病巣を診断しようとするものであ る.したがつて，一定の回転方式の下に迷路反応を測定 する徉来の検查法とは，全く異つた種類の検査法といら ことができる。

初めに基礎編において検查基準を定きた，次いで眩最 患者 156 例を対象に本検查を施行し, 次の結果を得た。

1. 異常型検出率は85\%で, 同一症例における cupulometry $974 \%$ りも高い.

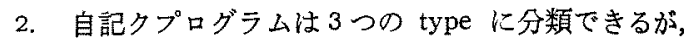
reversion phenomenon 陽性の Type 3 (Reversion type) は例外なく末梢疾患に認められる。

3. 末㭘疾患における reversion phenomenon 楛發率 は88\%と極めて高い.したがつてこの現象の有無によ り，病巣の末梢・中枢鑑別が可能である。

最後に, reversion phenomenon の成因を動物実験に ょり追求した。

\section{文献}

1) Bárány, R.: Untersuchungen über den von Vestibular apparat des Ohres reflektorisch ausgelösten rhythmischen Nystagmus und seine Begleiterscheinungen. Monatschr. f. Ohrenheilk., 40;191, 1906.

2) Báráay, $R$.: Weitere Untersuchungen über den von Vestibularapparat des Ohres reflektorisch ausgelösten rhythmischen Nystagmus und seine Begleiterscheinungen. Monatschr. f. Ohrenheilk., 41 ; 477, 1907.

3) Hallpike, C.S. \& Hood, J.D.: The Design, Construction and Performance of a New Type of Revolving Chair. Acta oto-laryng. (Stockh.), 42 ; 511, 1952.

4) Fischer, M.H. : Aktuelle Vestibularisfragen. Z. Laryng., $23 ; 398,1932$.

5) Egmond, A.A.J., Groen, J.J. \& Jongkees, L.B. $W .:$ The Turning Test with Small Regulable Stimuli-I.J. Laryng., $62 ; 63,1948$.

6) Hulk, J. \& Jongkees, L.B.W.: The Turning Test with Small Regulable Stimuli-II. J. Laryng., $62 ; 70$, 1948.

7) 朴沢二郎：矓罧を対象とした定量的前庭機能検查法

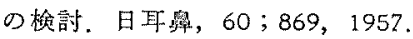

8）朴沢二郎：矓置を対象とした"Vestibular Asymmetry”の臨床的研究。日耳奥，64；1140，1961.

9) Aschan, G., Bergstedt, M. \& Stahle, J.: Nystagmography. Acta otolaryng. (Stockh.), Suppl., 129 ; 1956.

10) Stahle, J.: Electro-Nystagmography in the Caloric and Rotatory Tests. Acta oto-laryng. (Stockh.) Suppl., $137 ; 1958$.

11) Kobrak, F.: Zwei Vereinfachungen in der Vestibularisdiagnose. Acta oto-laryng. (Stockh.), 42 ; 96, 1952.

12) Wüst, H.: Untersuchung des Vestibularapparates mit neuen Drehschwachreizmethoden. Arch. Ohr.-, 
Nas.,,u. Kehlk.,-Heilk., 168 ; 414, 1956.

13）朴沢二郎：廻転中眼振を対象とせる簢易廻転椧查法 の試み。耳㬋, $33 ; 1039,1958$.

14) Reinecken, R.: Ergebnisse der Drehpendelprüfung bei Vestibulariserkrankten. Z. Laryng., 39 ; 820, 1960. 15) Reinecken, $R$. : Über das unterschiedliche Verhalten des Drehpendelprüfungsnystagmus gegenüber dem während der Drehung registrierten Nystagmus bei der rotatorischen Prüfung. Z. Laryng., 40; 203, 1961.

16) Boer, E. de, Carels, J. \& Philipszoon, A.J.: The Torsion Swing. Acta oto-laryng. (Stockh.). $56 ; 455$, 1963.

17) Greiner, G.F., Contraux, C. \& Picart, P.: Stimulations pendulaires dans l'examen vestibulaire. Acta oto-laryng. (Stockh.), $56 ; 338,1963$.

18）松永喬：バネ式隇衰回転椅子以上る回転検查法。日 耳盆, 65；1012，1962.

19）松永窝：振子様回転刺激による前庭機能検柤法の研 究. 日耳囱, $67 ; 1108,1964$.

20) Steinhausen, $W .:$ Über den experimentellen Nachweis der Ablenkung der Cupula terminalis in der intakten Bogengangsampulle des Labyrinths bei der thermischen und adäquaten rotatorischen Reizung. Zschrift. f. Hals Nasen u. Ohrenheilk., 29 ; $211,1931$.

21) Steinhausen, W.: Über die Wittmaacksche Turgorund Drucktheorie und die Mach-Breuersche Theorie der Verlagerung der Cupula terminalis in den Bogengängen des Vestibularapparates. Arch. Ohr.-,Nas.-, u. Kehlk.-, Heilk,, 132；134, 1932.

22) 朴沢二郎, 他：回䎐㭘査に関する研究。東北医誌, $67 ; 234,1963$.

23) 後藤敏郎監修:耳鼻㸶喉科学 (上巻)。医学書 院, 1960.

24）鳥居敏雄, 他：医学・生物学のための推計学. 東京 大学出版会, 1954.

25) Griffith, C.R.: Concerning the Effect of Repeated Rotation Upon Nystagmus. Laryngoscope, $30 ; 22$, 1920.

26) Hood, J.D. \& Pfaltz, C.R.: Observation Upon the Effects of Repeated Stimulation Upon Rotational and Caloric Nystagmus. J. Physiology, 124;130, 1954.

27）小倉孝：等角加速度超転装鳏に上る前庭機能検査法
に関する研究。日耳率，62；107，1959.

28) Fluur, E., Mendel, L. \& Lagerström, L.: Reproducibility of Duration of Latency Time in Unidirectional Per-Rotatory Nystagmus. Acta oto-laryng. (Stockh.), 62;118, 1966.

29) Egmond, A.A.J., Groen, J.J. \& Jongkees, L.B.W.: The Function of the Vestibular Organ. Pract. OtoRhino-Laryng., 14 ; Suppl., 2, 1952.

30) Mittermaier, $R$. \& Rossberg, G.: Vestibularisuntersuchungen mit schwellennahen Beschleunigungsreizen. Arch. Ohr.-, Nas.-, u. Kehlk.-Heilk., 168 ; 313, 1956.

31) Montandon, A. \& Russbach, A.: L'épreuve giratoire liminaire. Pract. Oto-Rhino-Laryng., $17 ; 224$, 1955.

32) Montandon, A. \& Fumeaux, J.: Valeur diagnostique comparative des nystagmus per-et postrotatoires à l'épreuve giratoire liminaire. Pract. Oto-RhinoLaryng,, $19 ; 556,1957$.

33）德增厚二, 他：回転眼振検査の椮討。耳舆臨休, $54 ; 952,1961$.

34）德增厚二：前庭機能検查に特りる回転中ならびに回 転後眼振の検討。日耳鼾, $65 ; 8,1962$.

35）朴沢二郎，他：電気眼振記録装置の使用小験。耳喉 $33 ; 773,1961$.

36) Montandon, A.: A New Technique for Vestibular Investigation. Acta oto-laryng. (Stockh.), 44;594, 1954.

37) Montandon, A., Monnier, M. \& Russbach, A.: A New Technique of Vestibular Rotatory Stimulation and of Electrical Recording of Nystagmus in Man. Ann. Otol. 64; 701, 1955.

38) Collins, W.E. \& Guedry, F.E.: Arousal Effects and Nystagmus During Prolonged Constant Angular Acceleration. Acta oto-laryng. (Stockh.), $54 ; 349$, 1962.

39) Ormerod, F.C.: Developments in the Recording of Nystagmoid Movement of the Eye. J. Laryng., $77 ; 171,1963$.

40) Jung, R. \& Mittermaier, R.: Zur objektiven Registrierung und Analyse verschiedener Nystagmusformen. Arch. Ohr.", Nas.-u. Kehlk.-Heilk., 146 ; 410, 1939. 
41) Torok, N., Guillemin, V. \& Barnothy, J.M.: Photoelectric Nystagmography. Ann. Otol., $60 ; 917$, 1951.

42) Pfaltz, C.R. \& Richter, H.S.R.: Photoelektrische Nystagmusregistrierung. Pract. Oto-Rhino-Laryng, $18 ; 263,1956$.

43) 朴沢二郎：電気的腿振記録法之光電学的眼振記䟿法 との比較研筑。耳喉, $34 ; 557,1962$.

44）朴沢二郎：テレビ,ビデオコーダーによる眼振の観 察・眏画並び新眼振記録法としてのテレニスタグモ グラフィーについて。昁番，67；1488，1964.

45) 朴沢二郎：ルーチンテストをしての平衡機能検査法

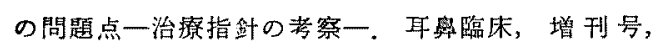
$2 ; 337,1966$,

46) Stenger, H.H.: "Erholungsnystagmus" nach einseitigen Vestibularisausfall, ein dem Bechterew-Nystagmus verwandter Vorgang. Arch. Ohr.-,Nas.-,u. Kehlk.-, Heilk., 175 ; 545. 1959.

47）森本正紀，他：聴力检査の手引。医学書院，1956.

48）切替一郎, 他: 㯖覚検査法. 医学毒院, 1964.

49) Azzi, A., Gioridano, R. \& Spelta, O.: Does a Vestibular Recruitment exist? Acta oto-laryng. (Stockh.), $43 ; 352,1953$.

50) Albano, G. : Vestibular Recruitment. Excerpta Med., $11 ; 326,1958$.

51) Horak, J.: Vestibular Recruitment. Zbl. Hals.Nas.-u. Ohrenheilk., 76;73, 1963.
52) Greiner, G.: Über dynamische Vestibulometrie mit Elektronystagmographie. Zbl. Hals.-Nas.-u. Ohrenheilk., $84 ; 293,1964$.

53) 池田繁: Vestibular Recruitment 現象に関する研 究。 日耳鬼, $67 ; 698,1964$.

54）武山頁次，他：温度刺激によるクブロメトリー，日 耳率, $61 ; 992,1958$.

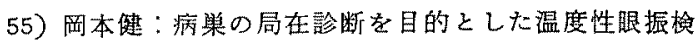
查法闺方研究。日耳鬼，62；250，1959.

56）小池吉郎：眼振所見よりみた眩䩤症，日耳學，第65 回総会シンポシウム報告別册，1964.

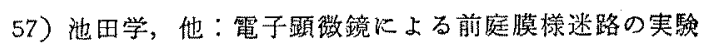
的研究一感觉細胞の受儌性について一。 日耳算, 68; $700,1965$.

稿を䅂るに臨み，御指導御校閱を睗つた恩師片桐

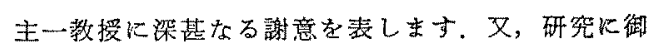
便宜を暘つた河本和友助教授，実䮖に際し親しく御

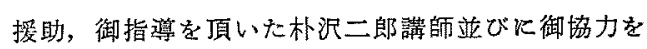
頂いた若山利力，石川嘉一博士に心から感謝いたし ます。

本論文の要旨は，第12，13回東北耳榃咽喉科連合 学会, 東北地方会第124,125,129,131，139，140 回例会，第65回日本耳奥咽喉科学会総会並びに第14 回日本前庭矿究会に拈いて報告した。

（原稿受付 昭和44.4.9日） 